\title{
New Composite Equalization Strategy for Lithium Battery Packs
}

\author{
Jiacheng Ni, Shichuan Wang, Kai Wu \\ Merchant Marine College, Shanghai Maritime University, Shanghai, China \\ Email: jiachengni@outlook.com
}

How to cite this paper: Ni, J.C., Wang, S.C. and $\mathrm{Wu}, \mathrm{K}$. (2019) New Composite Equalization Strategy for Lithium Battery Packs. Open Journal of Applied Sciences, 9, 172-180.

https://doi.org/10.4236/ojapps.2019.94015

Received: March 8, 2019

Accepted: April 14, 2019

Published: April 17, 2019

Copyright $\odot 2019$ by author(s) and Scientific Research Publishing Inc. This work is licensed under the Creative Commons Attribution International License (CC BY 4.0).

http://creativecommons.org/licenses/by/4.0/

(c) (i) Open Access

\begin{abstract}
In order to improve the working efficiency of the power battery pack and prolong the service life, there is a problem of inconsistency among the individual cells. Based on the centralized equalization structure of the multi-output winding transformer, a three-stage hybrid equalization control strategy is designed for equalization. The equalization scheme realizes that the high voltage single battery transfers the energy to the low voltage battery cell during the charging of the battery pack, improving not only charging efficiency and energy use loss, but also the high voltage battery transferring the power to the low voltage battery cell when the pressure difference is greater than $10 \mathrm{mv}$ during the discharge. Between $5 \mathrm{mv}$ and $10 \mathrm{mv}$, it performs passive equalization, reducing the output fluctuation of the power battery pack and achieving the balance purpose. During the standing time, the maximum active balancing operation within the battery pack is performed in order to achieve intra-group optimum consistency. It is proved by experiments that the equalization control method can realize the quick and effective equalization in the battery pack, and the energy balance of each single battery.
\end{abstract}

\section{Keywords}

Inconsistencies, Active Equalization, Energy Balance, Power Battery Pack

\section{Introduction}

For the performance of ships and the requirements of energy saving and emission reduction, electric propulsion ships have gradually become the clear direction of mainstream development for current marine engineering ships [1]. Lithium-ion battery packs are used for power supply units supporting electric high-speed diesel generators in conjunction with electric propulsion. The inconsistency is a major problem that distinguishes power battery packs from sin- 
gle-cell batteries [2]. Due to diverse factors such as the manufacturing process level and the actual environment, the overall performance of the battery pack will be affected by the actual health of the battery unit, which will affect the service life of the overall battery pack. Therefore, the research on the battery pack balancing strategy has far-reaching significance for improving the performance of the battery pack and prolonging the service life of the power battery pack [3].

In regard to the battery balancing strategy, it is divided into passive equalization and active equalization. Passive equalization, also known as energy dissipative equalization, consumes excess energy by paralleling the resistors across the cells to achieve equalization. The passive equalization strategy adopts a simpler circuit, a simpler control strategy, and lower cost. However, due to the equalization current is small, the time required for equalization is long and the equalization process continues to generate heat [4]. Because of that raises higher requirements in the thermal management of the power battery pack. Active equalization, also known as energy transfer equalization, enables energy to transfer between cells in a battery pack through energy storage components. The consumption of active equalization energy is small, the equalization time is short, and the efficiency is high, but the circuit structure and the controllable strategy are complicated and the cost is high. The literature [1] uses a two-way flyback converter, the battery cells in the battery pack can be more easily balanced, but the equilibrium speed is slower. The literature [2] [3] [4] [5] uses inductance as a relay carrier for energy to achieve energy transfer between two adjacent cells. However, the equalization strategy can only balance between two adjacent single cells, and the number of single cells of the power battery pack is extremely large, the control is difficult, and the cost of realization is high. The literature [11] [12] [13] [14] uses the capacitor as the carrier of the energy of the relay of the single cell, and realizes the charge and discharge of the capacitor and the different single cells in the battery by controlling the on and off of the switch. This circuit topology matches its control strategy, and the equalization time is longer and the equalization effect is not well. The literature [15] [16] realizes the equalization of different single cells in the battery pack by controlling the transformer, and the cost and the balanced power consumption increase due to the use of the transformer components.

In this paper, a novel composite circuit is proposed, and a set of matching equalization control strategies is designed to verify the experiment to prove that the proposed composite equalization strategy has practical effects and can achieve optimization.

\section{Design and Analysis of New Active Balancing Scheme}

\subsection{Composite Equalization Circuit Topology Design}

A passive equalization circuit that parallels a single single-cell battery with a single resistor and a single type of active equalization structure cannot fully achieve efficient equalization. Firstly, the flying capacitive equalization structure, the multi-output winding transformer centralized equalization structure, the Buck- 
Boost converter centralized equalization structure, the Buck-Boost converter distributed equalization structure and the three-cell direct interaction equalization structure are analyzed. A comparison of the performance of several typical balanced structures. It can be seen from the Table 1 that the integrated performance of the multi-output winding transformer centralized equalization structure of number 2 is more suitable as the reference structure of the active equalization part of the composite equalization structure. Therefore, this paper adopts the multi-output winding transformer centralized equalization structure as the circuit prototype of the active equalization part of the composite equalization structure circuit topology. The passive equalization part of the composite equalization structure is simply to connect the resistors in parallel next to the single cells.

The new composite equalization circuit is designed in this study is shown in Figure 1. Each cell is connected to a bidirectional switch, and has a resistor and switch in parallel. The left switch provides a charging loop, and the right switch
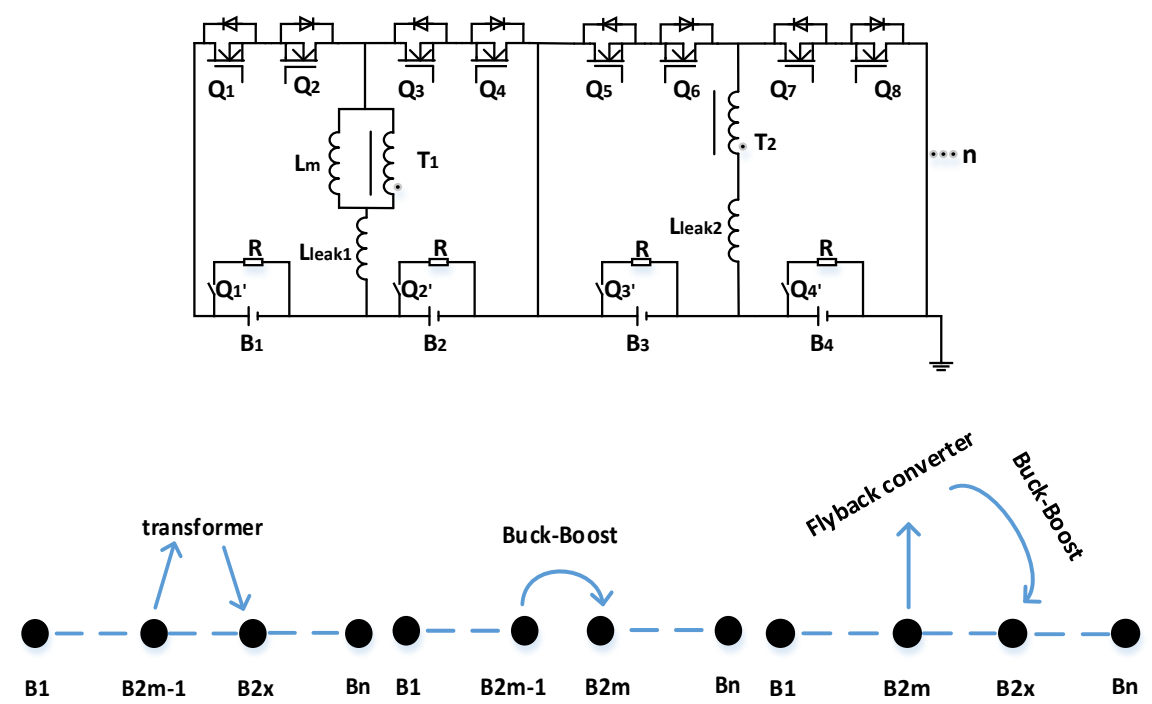

Figure 1. Composite equalization circuit topology.

Table 1. Comparison of each equalization circuit topology.

\begin{tabular}{|c|c|c|c|c|c|c|c|c|}
\hline \multirow{2}{*}{ Program } & \multicolumn{2}{|c|}{$\begin{array}{l}\text { Number of electronic } \\
\text { components }\end{array}$} & \multicolumn{2}{|c|}{$\begin{array}{l}\text { Component } \\
\text { voltage level }\end{array}$} & \multirow{2}{*}{$\begin{array}{l}\text { Number of } \\
\text { inductors }\end{array}$} & \multirow{2}{*}{$\begin{array}{l}\text { Number of } \\
\text { transformers }\end{array}$} & \multirow{2}{*}{$\begin{array}{c}\text { Battery } \\
\text { equalization speed }\end{array}$} & \multirow{2}{*}{$\begin{array}{l}\text { Control } \\
\text { Strategy }\end{array}$} \\
\hline & switch & diode & switch & diode & & & & \\
\hline 1 & 0 & 0 & 0 & 0 & 0 & 0 & A & $\mathrm{C}$ \\
\hline 2 & 1 & $\mathrm{~N}$ & $\mathrm{~N} * \mathrm{~V}$ & V & 0 & 1 & B & A \\
\hline 3 & $\mathrm{~N}$ & $\mathrm{~N}$ & $\mathrm{~V}$ & V & $\mathrm{N}-1$ & 0 & $\mathrm{C}$ & B \\
\hline 4 & $2 \mathrm{~N}-2$ & 0 & $\mathrm{~V}$ & V & $\mathrm{N}-1$ & 0 & B & B \\
\hline 5 & $2 \mathrm{~N}-2$ & 0 & $\mathrm{~V}$ & V & 0 & $(\mathrm{~N}-1) / 2(\mathrm{~N}>3)$ & A & B \\
\hline
\end{tabular}

(1-Flying capacitive equalization structure; 2-Multi-output winding transformer centralized equalization structure; 3-Buck-Boost centralized equilibrium structure; 4-Buck-Boost distributed equalization structure; 5 -Three-cell direct interaction equilibrium equalization structure). 
provides a discharge loop. The resistors are connected in parallel with the unit cells constitute a second discharge loop. The circuit consists of a simple switch, inductor, commutation circuit, and battery pack. Since DC/DC is not used, the cost is reduced. The equalization scheme is operated by the corresponding switching tube in the Buck-Boost or flyback converter mode to realize the equalization operation of the active equalization part, and the equalization operation of the passive equalization part is performed with the access resistance. In the active equalization operation, if the overcharged single cell number is an odd number and the single cell to be equalized is an even number, the switch tube on the right side of the overcharged single cell is closed, and the energy is to be equalized by the coupling of the primary and secondary sides of the transformer. In a single cell, the entire equalization process only needs one step, and vice versa; if the overcharged single cell is adjacent to the cell to be equalized, the equalized energy is directly transferred to the cell to be equalized through the Buck-Boost circuit. If the overcharged battery cell and the cell number to be equalized are both odd or even, the entire equalization process requires two steps. First, the energy is coupled through the flyback converter, and then through the Buck-Boost circuit, eventually the energy is transferred to the cell to be equalized. In the active equalization structure part, two adjacent battery cells share one current loop or share one transformer winding, so the number of transformer windings is reduced by half compared with the number of single cells, and the overall volume of the circuit is greatly reduced. Compared with other active equalization schemes, the equalization process uses the active equalization scheme can be completed in two steps, and the rate of equalization is greatly improved. In the passive equalization operation, according to the set control strategy, when the single cell power is too high, the resistor is connected for passive equalization operation.

\subsection{Balanced Strategy Design}

Based on the voltage equalization algorithm, the working state of the battery are equalized through using high-performance voltage detector to monitor the real-time voltage of each single cell, in order to achieve the consistent voltage between each battery cell. According to the previous experiment designs and results [1]-[19], the voltage state of the battery pack was analyzed under three different conditions. The equalization flow chart is shown in Figure 3. For achieving the best equalization result, the equalization strategy was designed as three phases: the static phase, the charging phase and the discharging stage.

1) When the battery pack is under the charging phase, the voltage value of each single battery in the battery pack is detected by the voltage collecting module, and then the battery pack was adjusted based on the real-time temperature of the battery pack, in order to obtain the more accurate battery cell voltage. Thus, the cell number with the largest voltage and the lowest voltage was detected. If the different value between $U_{\max }$ and $U_{\min }$ is less than the set value of 5 $\mathrm{mv}$, it is not necessary to turn on the equalization operation, and vice versa. The 
equalization operation period is $60 \mathrm{~s}$, and the detection is refreshed after $60 \mathrm{~s}$. This step could be repeated several times until the different value is less than the set value. In the charging phase, active balancing operation is selected, and the energy in high-voltage battery core was transferred into the low-voltage battery cell for achieving the equalization purpose. Moreover, the charging efficiency of the battery pack was accelerated, and the energy loss was minimized in this operation.

2) When the battery pack is under the discharging phase, the voltage value of each single battery in the battery pack is detected by the voltage collecting module, and then the battery pack was adjusted based on the real-time temperature of the battery pack, in order to obtain the more accurate battery cell voltage. Thus, the cell number with the largest voltage and the lowest voltage was detected. If the different value between $U_{\max }$ and $U_{\min }$ is larger than the first-order set value of $10 \mathrm{mv}$, the active balancing action was turn on for $U_{\max }$ battery and $\mathrm{U}_{\text {min }}$ battery. After the equalization action is performed for $30 \mathrm{~s}$. the difference value was compared with the second-order set value of $5 \mathrm{mv}$. If the different value is less than the set value of $5 \mathrm{mv}$, it is not necessary to turn on the equalization operation, and vice versa.

3) When the battery pack is in the stationary phase, the voltage value of each single battery in the battery pack is detected by the voltage collecting module, and then the battery pack was adjusted based on the real-time temperature of the battery pack, in order to obtain the more accurate battery cell voltage. Thus, the cell number with the largest voltage and the lowest voltage was detected. Then, the difference value between $U_{\max }$ and $U_{\text {min }}$ was compared with set value of $3 \mathrm{mv}$ to determine whether equalization operation should be performed. Since the state of the battery pack is relatively stable during the stationary phase, the low set value was selected, and the system refresh cycle was adjusted to $15 \mathrm{~s}$. These steps can adjust the battery pack to the best state and prolong the service life of the battery pack (Figure 2).

\section{Experimental Design and Verification}

In order to verify the equilibrium ability, equalization effect and feasibility of the new composite equalization strategy proposed in this paper, 12 lithium iron phosphate batteries were used in the experiment, and 2 and 12 strings were used to form the battery pack. BMS uses embedded processor, according to the voltage, temperature and other sensors which are equipped with the real-time voltage value of the single-cell battery and the temperature inside the battery pack, to determine whether the current battery pack is normal, and CAN communication with the host computer, according to the set control Strategy. Charge and discharge balance management of the battery pack. The structural connection of the equilibrium experimental system is shown in the Figure 3. The system software is programmed in C language and is modularized. It is developed on Metrowerks' CodeWarrior platform. 


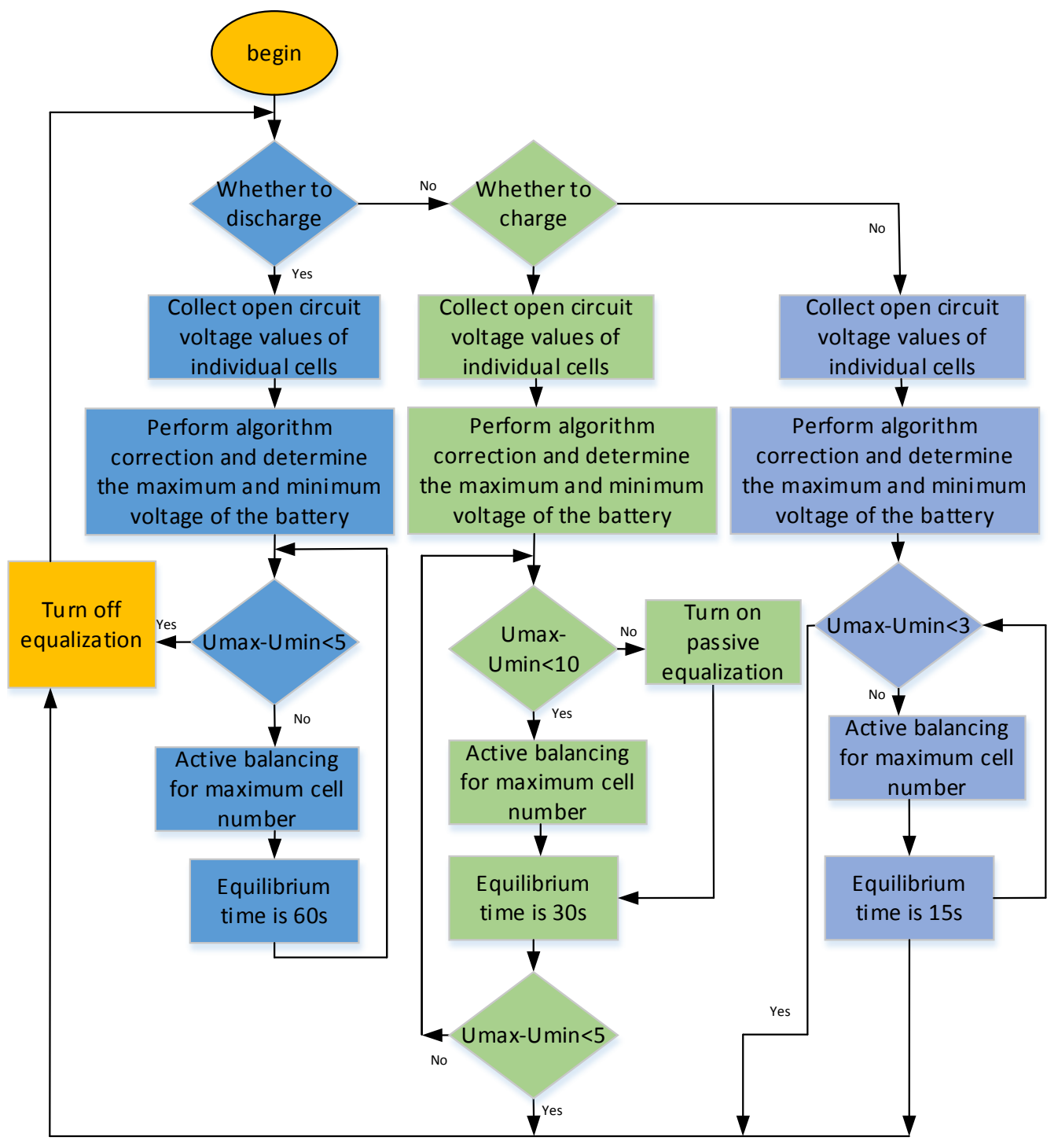

Figure 2. Composite equalization strategy flow chart.

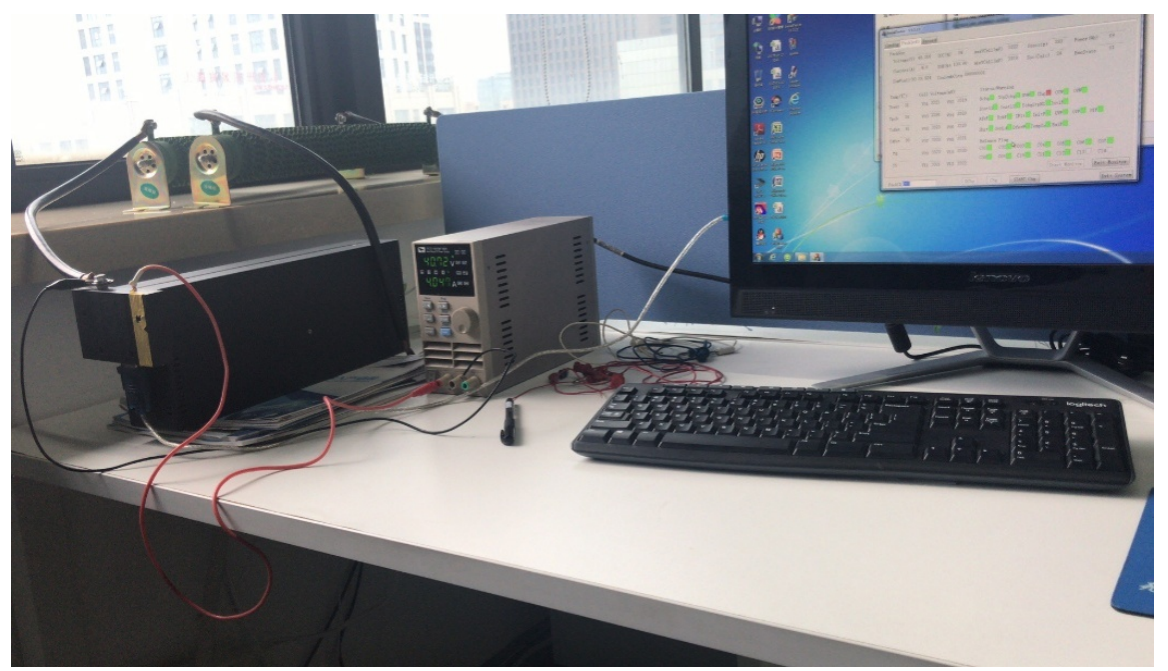

Figure 3. Equilibrium experiment wiring diagram. 


\section{Analysis of Results}

Figure 4 shows the real-time voltage of the 12 cells in a charge-discharge cycle of this design experiment. The case of Figure 5 appears when the equalization is on $6500 \mathrm{~s}$, the voltage value of cell No. 1 appears to be far away from other the case of voltage value of 11 sections indicates that there may be a problem with the No. 1 cell, but the voltage value of the cell No. 1 is gradually approached by the equalization effect from $6600 \mathrm{~s}$ to $7600 \mathrm{~s}$ after the occurrence of the situation, indicating that the equalization circuit and strategy equilibrium within the battery pack can be quickly achieved after a problem has occurred (Figure 6).

\section{Conclusion}

The imbalance phenomenon of power lithium battery pack is presented after multiple cycles of charging. This paper proposes a composite equalization circuit and equalization control strategy, and also has a test of them. The equalization strategy can quickly and effectively complete the imbalance in the battery pack. However, the voltage-based control strategy has certain defects. It still needs to be modified to improve the equalization effect eventually.

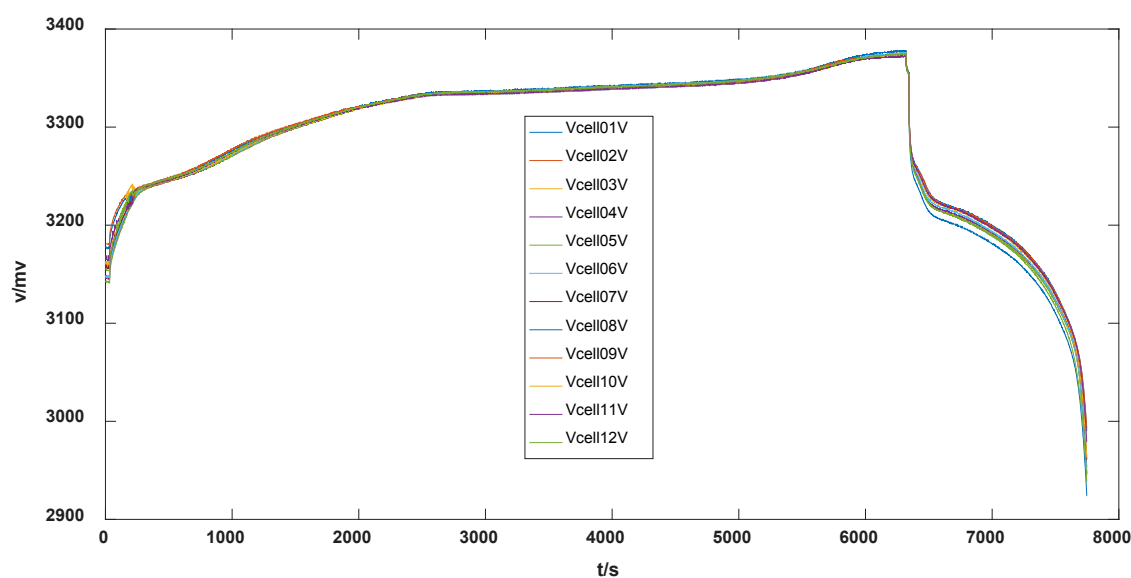

Figure 4. One charge and discharge experiment process.

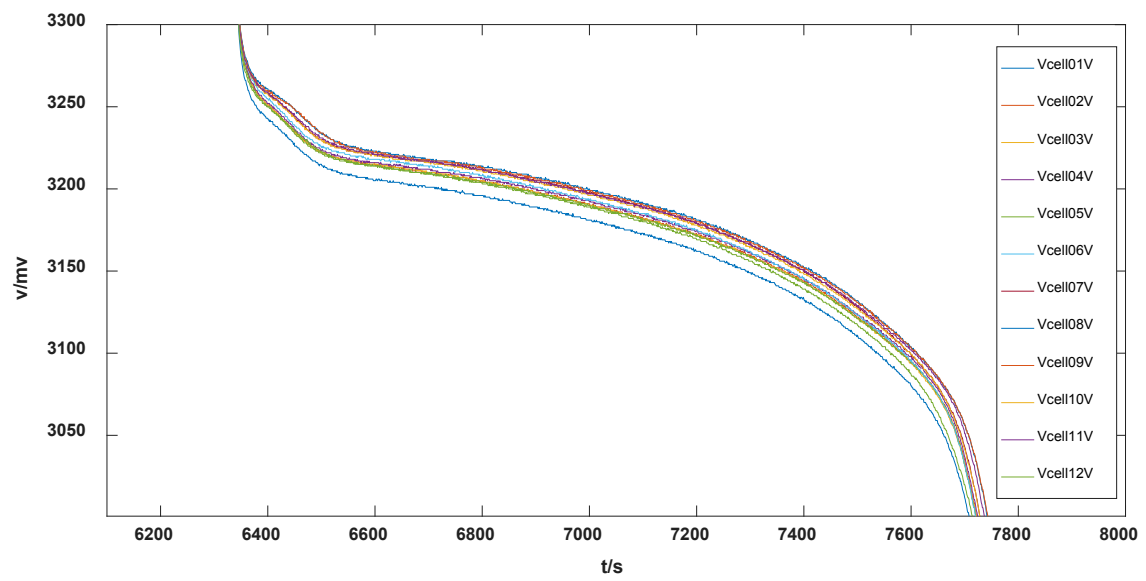

Figure 5. Equilibrium action during discharge experiments. 


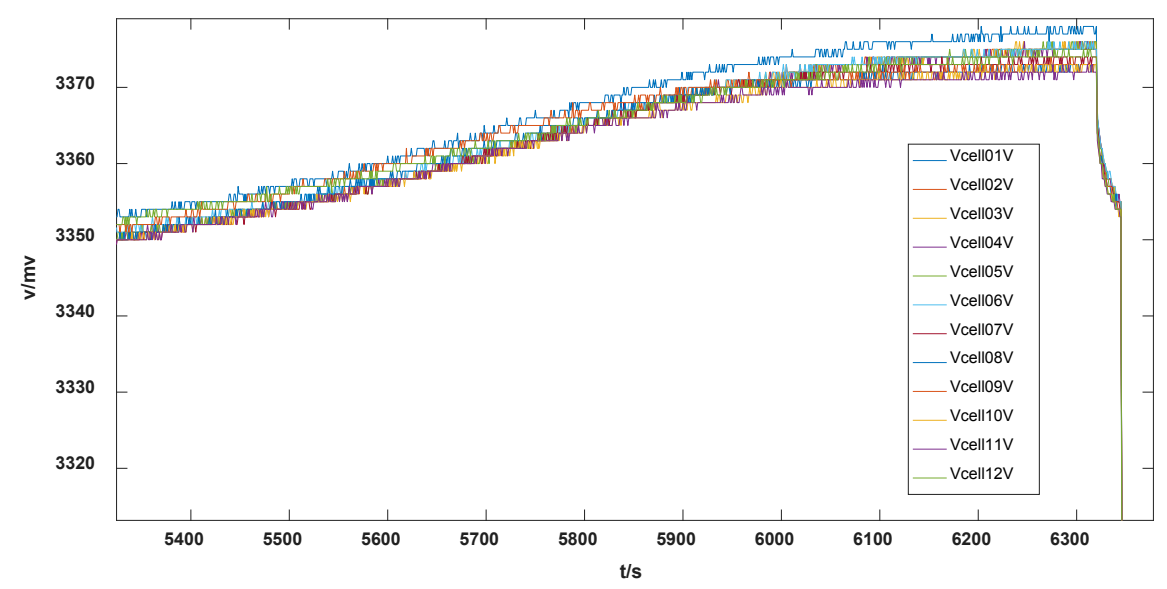

Figure 6. Partial schematic diagram of each cell being gradually filled during the experiment.

\section{Fund}

This work was supported by the National Natural Science Foundation of China (Grant No. 51779136), the National Natural Science Foundation of China (Grant No. 51179102).

\section{Conflicts of Interest}

The authors declare no conflicts of interest regarding the publication of this paper.

\section{References}

[1] Hoque, M.M., Hannan, M.A., Mohamed, A. and Ayob, A. (2017) Battery Charge Equalization Controller in Electric Vehicle Applications: A Review. Renewable and Sustainable Energy Reviews, 75, 1363-1385. https://doi.org/10.1016/j.rser.2016.11.126

[2] Diao, W.P., Xue, N., Bhattacharjee, V., Jiang, J., Karabasoglu, O. and Pecht, M. (2018) Active Battery Cell Equalization Based on Residual Available Energy Maximization. Applied Energy, 210, 690-698. https://doi.org/10.1016/j.apenergy.2017.07.137

[3] Yao, C., Zheng, X.C. and W, Z.W. (2014) Switched-Capacitor Charge Equalization Circuit for Series-Connected Batteries. 2014 International Power Electronics, Hiroshima, 18-21 May 2014, 429-432.

[4] Gao, M. (2010) Research on Dynamic Bidirectional Lossless Equalization Circuit Based on Energy Storage Inductor. Tianjin University, Tianjin.

[5] Zhao, N., Wang, Y., Yin, T.M. and Zhao, L.Y. (2017) Design and Control Strategy of Active Equalization Circuit for Lithium Iron Phosphate Battery Pack. Electronic Design Engineering, 25, 105-108.

[6] Lü, H., Liu, C.Z., Shen, J.S. and Jia, J.B. (2015) Optimization of Equilibrium Control Strategy for Lithium Iron Phosphate Battery Pack. Journal of Power Supply, 13, 107-112.

[7] Dai, H.F., Wei, X.Z., Sun, Z.H. and Chen, J.Q. (2013) Inductive Active Equalization System for Lithium Ion Power Battery for Electric Vehicles. Journal of Tongji Uni- 
versity, 41, 1547-1553.

[8] Vaclav, K., Daniel-Ioan, S. and Andreas, E., Propp, K., Fotouhi, A., Auger, D.J., Schaltz, E. and Teodorescu, R. (2017) Self-Balancing Feature of Lithium-Sulfur Batteries. Journal of Power Sources, 372, 245-251. https://doi.org/10.1016/j.jpowsour.2017.10.078

[9] Ren, H., Zhao, Y.Z., Chen, S.Z. and Wang, T.P. (2019) Design and Implementation of a Battery Management System with Active Charge Balance Based on the SOC and SOH Online Estimation. Energy, 166, 908-917. https://doi.org/10.1016/j.energy.2018.10.133

[10] Cheng, S.C., Jia, J.B., King, J.H., Wei, D.T., Gao, Z.C., Zhang, C.Z. and McCann, J. (2019) System Design of Underwater Battery Power System for Marine and Offshore Industry. Journal of Energy Storage, 21, 724-740.

https://doi.org/10.1016/j.est.2019.01.007

[11] Kimball, J.W. and Krein, P.T. (2005) Analysis and Design of Switched Capacitor Converters. Proceedings of the 20th Annual IEEE Applied Power Electronics Conference and Exposition, 3, 1473-1477. https://doi.org/10.1109/APEC.2005.1453227

[12] Pascual, C. and Krein, P.T. (1997) Switched Capacitor System for Automatic Series Battery Equalization. IEEE Applied Power Electronics Conference and Exposition, 2, 848-854. https://doi.org/10.1109/APEC.1997.575744

[13] Nishijima, K., Sakamoto, H. and Harada, K.A. (2000) PWM Controlled Simple and High Performance Battery Balancing System. IEEE Annual Power Electronics Specialists Conference, 1, 517-520. https://doi.org/10.1109/PESC.2000.878916

[14] Liu, H.R. and Xia, C.X. (2013) An Investigation into a New Battery Balancing Solution for Electric Vehicles. Automotive Engineering, 35, 934-938.

[15] Einhorn, M., Roessler, W. and Fleig, J. (2011) Improved Performance of Serially Connected Li-Ion Batteries with Active Cell Balancing in Electric Vehicles. IEEE Transactions on Vehicular Technology, 60, 2448-2457. https://doi.org/10.1109/TVT.2011.2153886

[16] Wang, Y., Zhang, C., Chen, Z., et al. (2015) A Novel Active Equalization Method for Lithium-Ion Batteries in Electric Vehicles. Applied Energy, 145, 36-42. https://doi.org/10.1016/j.apenergy.2015.01.127

[17] Christopher, O., Dirk, U.S. and Michael, M. (2019) Bidding Strategy for a Battery Storage in the German Secondary Balancing Power Market. Journal of Energy Storage, 21, 787-800. https://doi.org/10.1016/j.est.2019.01.019

[18] Marlou, K., Alberto, V. and Stefano, P. (2018) Hybrid Electrolytes for Lithium Metal Batteries. Journal of Power Sources, 392, 206-225. https://doi.org/10.1016/j.jpowsour.2018.04.099

[19] Wang, Y.J., Zhang, C.B., Chen, Z.H., Xie, J. and Zhang, X. (2015) A Novel Active Equalization Method for Lithium-Ion Batteries in Electric Vehicles. Applied Energy, 145, 36-42. https://doi.org/10.1016/j.apenergy.2015.01.127 